\title{
PEMETAAN PENYAKIT DEMAM BERDARAH DENGUE DENGAN ANALISIS POLA SPASIAL DI KABUPATEN PEKALONGAN
}

\author{
Hasbi Yasin ${ }^{1}$, Ragil Saputra ${ }^{2}$ \\ ${ }^{1}$ Jurusan Statistika FSM UNDIP \\ ${ }^{2}$ Jurusan Informatika FSM UNDIP
}

\begin{abstract}
The number of dengue haemorrhagic fever (DHF) incidence in Pekalongan from year to year is very volatile. In 2006, there was 352 cases, 718 cases occurred in 2007, 2008 saw 403 cases, 2009 there were 753 cases, whereas in 2010 a decline to 223 cases. This is possible due to the lack of information about the place, time and location of the incident spread of dengue in Pekalongan. Various efforts have been made to address these issues both society and government but the incidence of this disease has not been effectively suppressed. The results of data analysis showed that the incidence of dengue in Pekalongan mostly occurs during the rainy season is the period from January to June. The DHF incidence tends to be higher in Kedungwuni. Highest incidence of DHF occurred in April 2010. In addition, there are some months that indicate the spatial relationships in the incidence of dengue in Pekalongan, ie January, February, July, October and December. The sub-district that has a positive autocorrelation is Kedungwuni, Wonopringgo, and Tirto. While the sub-district has a negative autocorrelation is Karangdadap. Most of the subdistricts in Pekalongan status is still endemic for dengue.
\end{abstract}

Keywords: DHF, Moran's Index, Spatial Pattern

\section{Pendahuluan}

Menurut Ginanjar (2004) ${ }^{[3]}$, Demam Berdarah Dengue (DBD) merupakan penyakit yang disebabkan oleh virus dengue yang ditularkan melalui gigitan nyamuk Aedes aegypti dan Aedes albopictus yang sebelumnya telah terinfeksi oleh virus dengue dari penderita DBD lainnya. Kedua jenis nyamuk Aedes ini terdapat hampir di seluruh pelosok Indonesia. Populasi nyamuk ini akan meningkat pesat pada saat musim hujan. Berbagai upaya telah dilakukan untuk mengatasi permasalahan ini baik masyarakat maupun pemerintah, namun angka terjangkitnya penyakit ini masih belum dapat ditekan secara efektif.

Berdasarkan profil kesehatan Kabupaten Pekalongan tahun $2011^{[2]}$ penyakit DBD telah menyebar luas ke seluruh wilayah Kabupaten Pekalongan. Dari tahun ke tahun jumlah penderita DBD cenderung fluktuatif. Pada tahun 2006 terjadi 352 kasus, 2007 terjadi 718 kasus, 2008 terjadi 403 kasus, 2009 terjadi 753 kasus, sedangkan pada tahun 2010 menurun menjadi 223 kasus. Hal ini karena kurangnya informasi mengenai tempat, waktu dan lokasi persebaran kejadian DBD di Kabupaten Pekalongan.

Peta sebaran secara geografis penyakit sangat berguna untuk mempelajari hubungan antara iklim dengan penyakit atau masalah kesehatan lain secara empirik dan bermanfaat untuk membantu mengimplementasikan rencana intervensi. Informasi sebaran wilayah rawan menurut tempat dan waktu diperlukan dalam menentukan wilayah prioritas pelaksanaan program antisipasi dan penanggulangan. Serangkaian kegiatan pemberian peringatan sesegera mungkin kepada masyarakat tentang kemungkinan terjadinya bencana disuatu tempat oleh lembaga yang berwenang disebut dengan sistem peringatan dini atau early warning system (UU No.24 tahun 2007). Oleh karena itu, dibutuhkan peta sebaran yang diharapkan mampu untuk menentukan wilayah prioritas pelaksanaan program antisipasi dan penanggulangan wabah DBD di Kabupaten Pekalongan. 
Beberapa penelitian yang pernah dilakukan yang berhubungan dengan penyakit DBD adalah model peringatan dini penyakit demam berdarah dengan menggunakan faktor iklim diantaranya: Sasmito, Gunaman, dan Widiatmoko $(2006)^{[7]}$ yang menyusun model peringatan dini DBD di Kota Jakarta. Menurut Rosli et al. (2010) ${ }^{[6]}$, dalam penelitian kesehatan, analisis spasial digunakan untuk mendeteksi dan mengukur pola kejadian penyakit yang dapat memberikan wawasan epidemiologi penyakit. Dalam kasus ini analisis spasial dilakukan dengan dua langkah yaitu menentukan autokorelasi spasial yang terjadi dalam ruang unit untuk menentukan pola kejadian penyakit dan membuat pemetaan penyakit.

Penelitian ini akan menyusun peta rawan persebaran kejadian penyakit DBD di Kabupaten Pekalongan dengan mempertimbangkan lokasi (kecamatan), waktu (bulan), dan musim dengan pendekatan analisis pola spasial (spatial pattern analysis). Metode ini cukup baik dalam menyajikan peta kerawanan penyakit sekaligus dapat megidentifikasi keterkaitan antar lokasi dan waktu ${ }^{[1]}$. Metode ini juga sangat efektif dalam mendeteksi variasi secara geografi ${ }^{[8]}$. Dengan melakukan penelitian ini diharapkan memberikan masukan kepada instansi terkait untuk mencegah terjadinya kasus demam berdarah.

\section{Tinjauan Pustaka Bahan dan Metode Spatial Autocorrelation}

Autokorelasi spasial adalah korelasi antara variabel dengan dirinya sendiri berdasarkan ruang atau dapat juga diartikan suatu ukuran kemiripan dari objek di dalam suatu ruang (jarak, waktu dan wilayah). Jika terdapat pola sistematik di dalam penyebaran sebuah variabel, maka terdapat autokorelasi spasial. Adanya autokorelasi spasial mengindikasikan bahwa nilai atribut pada daerah tertentu terkait oleh nilai atribut tersebut pada daerah lain yang letaknya berdekatan atau bertetangga ${ }^{[1]}$.

\section{Matrik Pembobot Spasial}

Matrik pembobot spasial dapat ditentukan dengan beragam metode. Salah satu metode penentuan matrik pembobot spasial yang digunakan dalam penelitian ini adalah Queen contiguity (persinggungan sisi-sudut). Matrik pembobot $w_{i j}$ berukuran $n \times n$, dimana setiap elemen matrik menggambarkan ukuran kedekatan antara pengamatan $i$ dan $j$.

Pada Gambar 1 diberikan ilustrasi mengenai perhitungan matrik pembobot menggunakan Queen contiguity. Ilustrasi tersebut menggunakan lima daerah sebagai pengamatannya. Elemen matrik didefinisikan 1 untuk wilayah yang bersisian (common side) atau titik sudutnya (common vertex) bertemu dengan daerah yang menjadi perhatian, sedangkan daerah lainnya didefinisikan elemen matrik pembobot sebesar nol. Untuk daerah 3, didapatkan $w_{31}=0, w_{32}=1, w_{33}=0, w_{34}=1$, dan $w_{35}=1$. Matrik $w_{i j}$ ini memiliki ukuran matrik 5 x 5 . Ilustrasi lebih lengkapnya disajikan pada Gambar 1 berikut

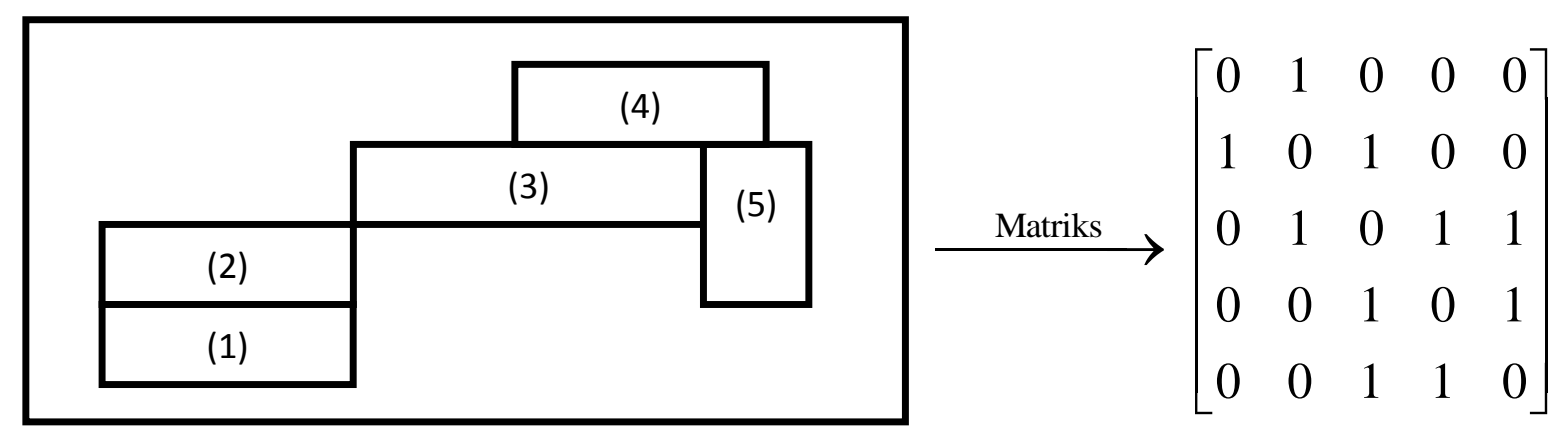

Gambar 1. Ilustrasi Perhitungan Matriks Pembobot Contiguity 


\section{Indeks Moran's I}

Moran's I mengukur korelasi satu variabel misal $x\left(x_{i}\right.$ dan $\left.x_{j}\right)$ dimana $i \neq j$, $i=1,2, \ldots n, j=1,2, \ldots n$ dengan banyak data sebesar $n$, maka formula dari Moran's $I$ adalah pada Persamaan $(1)^{[5]}$.

$$
\begin{aligned}
& I=\frac{n \sum_{i=1}^{n} \sum_{j=1}^{n} w_{i j}\left(x_{i}-\bar{x}\right)\left(x_{j}-\bar{x}\right)}{S_{0} \sum_{j=1}^{n}\left(x_{i}-\bar{x}\right)^{2}} \\
& S_{0}=\sum_{i=1}^{n} \sum_{j=1}^{n} w_{i j}
\end{aligned}
$$

$\bar{x}$ pada Persamaan (1) merupakan rata-rata dari variabel $x, w_{i j}$ merupakan elemen dari matrik pembobot, dan $S_{0}$ adalah jumlahan dari elemen matrik pembobot. Nilai dari indeks $I$ ini berkisar antara -1 dan 1 . Identifikasi pola menggunakan kriteria nilai indeks $I$, jika $I>I_{0}$, maka mempunyai pola mengelompok (cluster), jika $I>I_{0}$, maka berpola menyebar tidak merata (tidak ada autokorelasi), dan $I<I_{0}$, memiliki pola menyebar. $I_{0}$ merupakan nilai ekspektasi dari I yang dirumuskan sebagai berikut ${ }^{[4]}$ :

$$
E(I)=I_{0}=\frac{-1}{n-1} \text {. }
$$

Pengujian hipotesis terhadap parameter $I$ dapat dilakukan sebagai berikut.

$\mathrm{H}_{0}$ : tidak ada autokorelasi spasial

$\mathrm{H}_{1}$ : terdapat autokorelasi positif (indeks Moran's I bernilai positif)

$\mathrm{H}_{1}$ : terdapat autokorelasi negatif (indeks Moran's I bernilai negatif ).

Menurut Lee dan Wong ${ }^{[4]}$ statistik uji dari indeks Moran's $I$ diturunkan dalam bentuk statistik peubah acak normal baku. Hal ini didasarkan pada teori Dalil Limit Pusat dimana untuk n yang besar dan ragam diketahui maka $Z(I)$ akan menyebar normal baku sebagai berikut:

$$
Z_{h i t}=\frac{I-E(I)}{\sqrt{\operatorname{var}(I)}}
$$

dengan $I$ adalah indeks Moran's $I, Z_{\text {hit }}$ adalah nilai statistik uji indeks Moran's $I, \mathrm{E}(I)$ adalahnilai ekspektasi indeks Moran's $I$, dan $\operatorname{Var}(I)$ adalah nilai varians dari indeks Moran's $I$.

$$
\operatorname{Var}(I)=\frac{n\left\{\left(n^{2}-3 n+3\right) S_{1}-n S_{2}+3 S_{0}^{2}\right\}}{(n-1)(n-2)(n-3) S_{0}^{2}}-\frac{k\left\{n(n-1) S_{1}-2 n S_{2}+6 S_{0}^{2}\right\}}{(n-1)(n-2)(n-3) S_{0}^{2}}-\frac{1}{(n-1)^{2}}
$$

dengan:

$$
\begin{aligned}
S_{1} & =\frac{1}{2} \sum_{i=1}^{n} \sum_{j=1}^{n}\left(w_{i j}+w_{j i}\right)^{2}, S_{2}=\frac{1}{2} \sum_{i=1}^{n}\left(w_{i .}+w_{. i}\right)^{2}, w_{i .}=\sum_{j=1}^{n} w_{i j} \text { dan } w_{. i}=\sum_{j=1}^{n} w_{j i} \\
k & =\frac{\sum_{i=1}^{n}\left(x_{i}-\bar{x}\right)^{4}}{\left(\sum_{i=1}^{n}\left(x_{i}-\bar{x}\right)^{2}\right)^{2}}
\end{aligned}
$$

Pengujian ini akan menolak hipotesis awal jika nilai $\mathrm{Z}_{\mathrm{hit}}>\mathrm{Z}(\alpha)$ (autokorelasi positif) atau $Z_{\text {hit }}>-\mathrm{Z}(\alpha)$ (autokorelasi negatif). Positif autokorelasi spasial megindikasikan bahwa antar lokasi pengamatan memiliki keeratan hubungan. 


\section{Local Indicator of Spatial Autocorrelation (LISA)}

Pengidentifikasian koefisien autocorrelation secara lokal dalam artian menemukan korelasi spasial pada setiap daerah, dapat digunakan Moran's I. Moran's Ipada LISA mengindikasikan local autocorrelation. LISA disini mengidentifikasi bagaimana hubungan antara suatu lokasi pengamatan terhadap lokasi pengamatan yang lainnya. Adapun indeksnya adalah sebagai berikut ${ }^{[4]}$ :

$$
I_{i}=z_{i} \sum_{i=1}^{n} w_{i j} z_{j}
$$

$z_{i}$ dan $z_{j}$ pada persamaan (3) merupakan deviasi dari nilai rata-rata.

$$
z_{i}=\left(x_{i}-\bar{x}\right) / \delta
$$

$\delta$ adalah nilai standar deviasi dari $x_{i}$.

Pengujian terhadap parameter $I_{i}$ dapat dilakukan sebagai berikut.

$\mathrm{H}_{0}$ : tidak ada autokorelasi spasial

$\mathrm{H}_{1}$ : terdapat autokorelasi spasial

Statistik uji: $Z_{h i t}=\frac{I_{i}-E\left(I_{i}\right)}{\sqrt{\operatorname{Var}\left(I_{i}\right)}}$

dengan $I_{i}$ merupakan indeks LISA, $Z_{\text {hit }}$ merupakan nilai statistik uji indeks LISA, $E\left(I_{i}\right)$ merupakan nilai ekspektasi indeks LISA, dan $\operatorname{var}\left(I_{i}\right)$ merupakan nilai varians dari indeks LISA.

$$
E\left(I_{i}\right)=\frac{-w_{i .}}{n-1}
$$

Pengujian ini akan menolak hipotesis awal jika nilai $Z_{\text {hit }}$ terletak pada $\left|Z_{h i t}\right|>Z(\alpha / 2)$.

\section{Moran's Scatterplot}

Lee dan Wong (2001) ${ }^{[4]}$ menyebutkan bahwa Moran's Scatterplot adalah salah satu cara untuk menginterpretasikan statistik Indeks Moran. Moran's Scatterplot merupakan alat untuk melihat hubungan antara (nilai pengamatan yang sudah distandarisasi) dengan (nilai rata-rata daerah tetangga yang telah distandarisasi). Ilustrasi lebih lengkap dapat dilihat pada Gambar 2 di bawah ini.

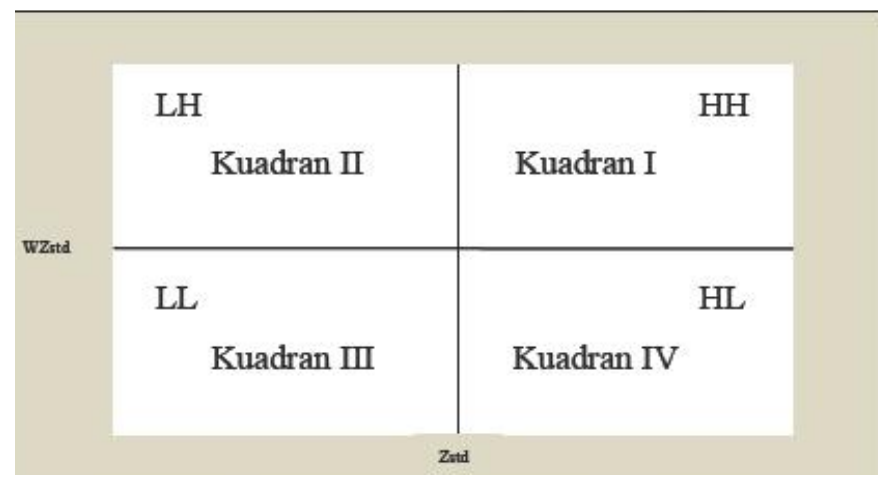

Gambar 2. Moran Scatterplot

Kuadran I (terletak di kanan atas) disebut High-High $(\mathrm{HH})$, menunjukkan daerah yang mempunyai nilai pengamatan tinggi dikelilingi oleh daerah yang mempunyai nilai 
pengamatan tinggi. Kuadran II (terletak di kiri atas) disebut Low-High (LH), menunjukkan daerah dengan pengamatan rendah tapi dikelilingi daerah dengan nilai pengamatan tinggi. Kuadran III (terletak di kiri bawah) disebut Low-Low (LL), menunjukkan daerah dengan nilai pengamatan rendah dan dikelilingi daerah yang juga mempunyai nilai pengamatan rendah. Kuadran IV (terletak di kanan bawah) disebut High-Low (HL), menunjukkan daerah dengan nilai pengamatan tinggi yang dikelilingi oleh daerah dengan nilai pengamatan rendah. Moran's Scatterplot yang banyak menempatkan pengamatan di kuadran $\mathrm{HH}$ dan kuadran LL akan cenderung mempunyai nilai autokorelasi spasial yang positif (cluster). Sedangkan Moran's Scatterplot yang banyak menempatkan pengamatan di kuadran HL dan LH akan cenderung mempunyai nilai autokorelasi spasial yang negatif.

\section{Hasil dan Pembahasan}

\section{Keaadaan Geografis Kabupaten Pekalongan}

Kabupaten Pekalongan merupakan salah satu dari 35 Kabupaten/Kota di Provinsi Jawa Tengah, yang berada di daerah Pantura bagian barat sepanjang pantai utara Laut Jawa memanjang ke selatan dengan Kota Kajen sebagai Ibu Kota pusat pemerintahan.

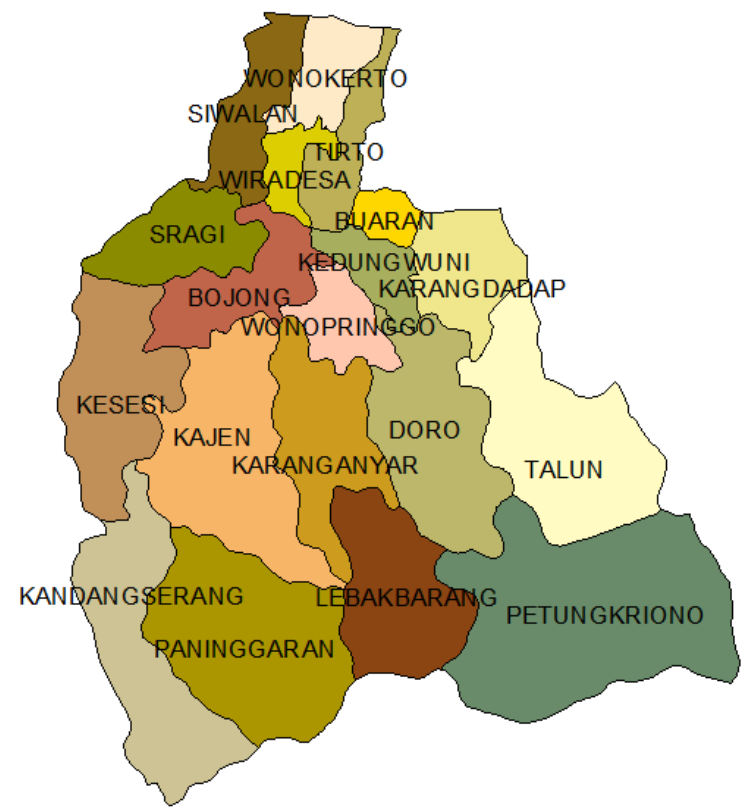

Gambar 3. Peta Administrasi Kabupaten Pekalongan

\section{Kejadian Penyakit DBD Menurut Kecamatan}

Kejadian penyakit DBD di Kabupaten Pekalongan pada periode 2010 sampai 2011 memiliki karakteristik yang beragam. Rata-rata tertinggi angka kejadian DBD adalah sebesar 3.58 perbulan yang terjadi di kecamatan Kedungwuni, sedangkan ada beberapa kecamatan yang tidak pernah muncul adanya kejadian penyakit DBD yaitu di kecamatan Kandangserang, Lebakbarang dan Petungkriono. Sedangkan keragaman tertinggi adalah sebesar 6.43 yang terjadi di kecamatan Kedungwuni. Deskripsi secara lengkap kejadian penyakit DBD di Kabupaten Pekalongan menurut kecamatan periode 2010-2011 disajikan pada Tabel 1.

Tingginya kejadian penyakit DBD di Kecamatan Kedungwuni tidak lepas dari besarnya kepadatan penduduk yang ada pada wilayah tersebut. Kecamatan-kecamatan dengan kepadatan penduduk yang cukup tinggi terjadi di kecamatan Kedungwuni, Tirto, Wiradesa, dan Buaran. Kecamatan Buaran merupakan kecamatan dengan kepadatan 
penduduk tertinggi yaitu sebesar lebih dari $4538 \mathrm{jiwa} / \mathrm{km}^{2}$. Selengkapnya dapat dilihat pada Gambar 4.

Tabel 1. Nilai Rata-rata dan Ragam Jumlah Kejadian Penyakit DBD Tiap Bulan di Kabupaten Pekalongan Tahun 2010 sampai 2011 Menurut Kecamatan

\begin{tabular}{lcclcc}
\hline Kecamatan & Rata-rata & Ragam & Kecamatan & Rata-rata & Ragam \\
\hline Buaran & 1.50 & 2.26 & Siwalan & 0.13 & 0.11 \\
Doro & 0.63 & 1.46 & Sragi & 0.17 & 0.23 \\
Kajen & 0.88 & 0.81 & Talun & 0.13 & 0.11 \\
Kandangserang & 0.00 & 0.00 & Tirto & 0.38 & 0.42 \\
Karangdadap & 0.50 & 0.87 & Wiradesa & 0.54 & 0.61 \\
Kedungwuni & 3.58 & 6.43 & Wonokerto & 0.17 & 0.23 \\
Kesesi & 1.04 & 1.09 & Wonopringgo & 0.83 & 0.93 \\
Lebakbarang & 0.00 & 0.00 & Karanganyar & 0.46 & 0.61 \\
Paninggaran & 0.17 & 0.14 & Bojong & 1.42 & 2.34 \\
Petungkriono & 0.00 & 0.00 & & & \\
\hline
\end{tabular}

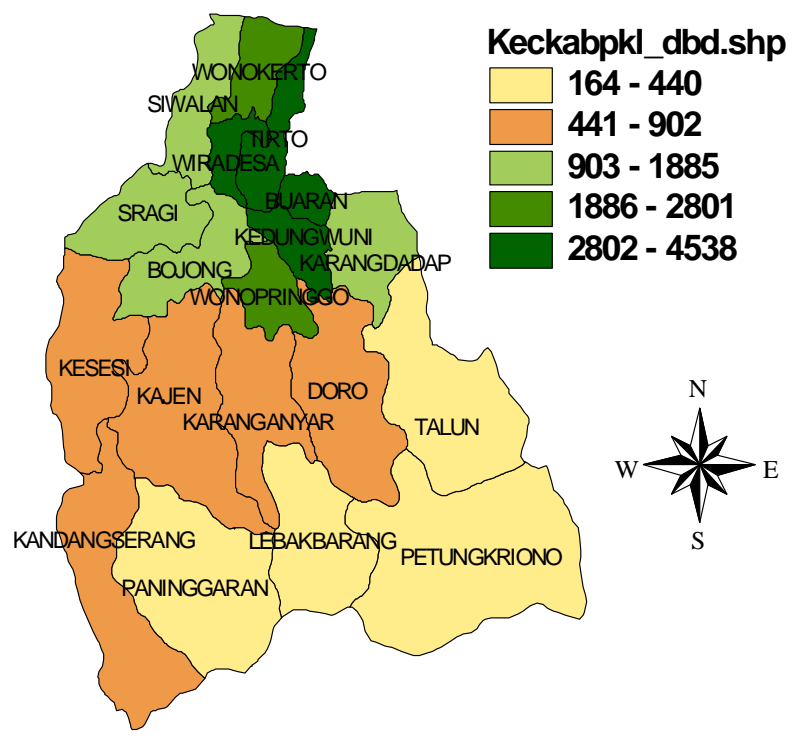

Gambar 4. Kepadatan Penduduk Kabupaten Pekalongan Menurut Kecamatan Tahun 2011

\section{Kejadian Penyakit DBD Menurut Waktu}

Berdasarkan waktu kejadian penyakit DBD di Kabupaten Pekalongan pada periode 20102011 menunjukkan bahwa kejadian DBD paling banyak terjadi pada semester pertama, yaitu bulan Januari-Juni. Periode ini merupakan musim hujan (Desember-Maret) dan musim transisi menuju kemarau (April-Juni). Sebaliknya, pada bulan Juli-Desember atau semester kedua kejadian DBD cenderung lebih rendah karena bulan-bulan ini merupakan musim kemarau (Juni-September) dan transisi menuju musim hujan (Oktober-Desember). Selama periode 2010-2011 kejadian DBD terbesar adalah pada bulan April dan Mei 2010, sedangkan pada bulan Juli 2011 dan Agustus 2011 merupakan bulan dengan angka kejadian penyakit DBD terrendah. 


\section{Hubungan Kejadian DBD Antar Kecamatan dan Pola Sebarannya}

Pada tahun 2010 menunjukkan bahwa pada bulan Januari, Februari, Juli, Oktober dan Desember memiliki pola penyebaran kejadian DBD yang mengelompok. Hal ini berarti bahwa angka kejadian DBD antar kecamatan pada beberapa bulan tersebut hampir sama. Sementara pada bulan-bulan yang lain diindikasikan angka kejadian DBD-nya tidak membentuk kelompok yang berarti bahwa angka kejadian DBD antar kecamatan pada bulan tersebut cukup beragam. Sedangkan pada tahun 2011 tidak terdapat periode bulan yang memiliki pola penyebaran kejadian DBD yang mengelompok. Hal ini berarti bahwa angka kejadian DBD antar kecamatan pada beberapa bulan tersebut hampir sama tidak membentuk kelompok yang berarti bahwa angka kejadian DBD antar kecamatan pada bulan tersebut cukup beragam.

Tabel 2. Hasil Perhitungan Indeks Moran's $I, \mathrm{E}(I), \operatorname{Var}(I)$, dan $Z_{\text {hitung }}$ tahun 2010

\begin{tabular}{lcccrl}
\hline Bulan & $\boldsymbol{I}$ & $\mathbf{E}(\boldsymbol{I})$ & $\operatorname{Var}(\boldsymbol{I})$ & Zhitung & Pvalue \\
\hline Januari & 0.1523 & -0.0556 & 0.0057 & 2.7652 & $0.0028^{\mathrm{a}}$ \\
Februari & 0.3691 & -0.0556 & 0.0142 & 3.5611 & $0.0002^{\mathrm{a}}$ \\
Maret & 0.1080 & -0.0556 & 0.0139 & 1.3901 & 0.0823 \\
April & 0.0664 & -0.0556 & 0.0108 & 1.1735 & 0.1204 \\
Mei & 0.1100 & -0.0556 & 0.0142 & 1.3897 & 0.0823 \\
Juni & 0.0627 & -0.0556 & 0.0143 & 0.9908 & 0.1609 \\
Juli & 0.1706 & -0.0556 & 0.0186 & 1.6601 & $0.0485^{\mathrm{b}}$ \\
Agustus & 0.1311 & -0.0556 & 0.0191 & 1.3517 & 0.0883 \\
September & -0.0313 & -0.0556 & 0.0178 & 0.1819 & 0.4278 \\
Oktober & 0.1884 & -0.0556 & 0.0172 & 1.8624 & $0.0313^{\mathrm{b}}$ \\
Nopember & 0.0686 & -0.0556 & 0.0166 & 0.9653 & 0.1672 \\
Desember & 0.1223 & -0.0556 & 0.0084 & 1.9427 & $0.0261^{\mathrm{b}}$ \\
\hline
\end{tabular}

${ }^{\mathrm{a}}$ Signifikan pada $\alpha=1 \%,{ }^{\mathrm{b}}$ Signifikan pada $\alpha=5 \%$

Tabel 3. Hasil Perhitungan Indeks Moran's $I, \mathrm{E}(I), \operatorname{Var}(I)$, dan $Z_{\text {hitung }}$ tahun 2011

\begin{tabular}{lcccrc}
\hline Bulan & $\boldsymbol{I}$ & $\mathbf{E}(\boldsymbol{I})$ & $\operatorname{Var}(\boldsymbol{I})$ & Zhitung & Pvalue \\
\hline Januari & 0.0466 & -0.0556 & 0.0169 & 0.7857 & 0.2161 \\
Februari & -0.1050 & -0.0556 & 0.0136 & -0.4236 & 0.6642 \\
Maret & -0.0255 & -0.0556 & 0.0160 & 0.2379 & 0.4062 \\
April & -0.1457 & -0.0556 & 0.0121 & -0.8192 & 0.7939 \\
Mei & 0.0695 & -0.0556 & 0.0160 & 0.9887 & 0.1615 \\
Juni & -0.1526 & -0.0556 & 0.0170 & -0.7431 & 0.7714 \\
Juli & -0.1715 & -0.0556 & 0.0123 & -1.0466 & 0.8524 \\
Agustus & -0.0484 & -0.0556 & 0.0005 & 0.3310 & 0.3706 \\
September & -0.1432 & -0.0556 & 0.0177 & -0.6580 & 0.7448 \\
Oktober & -0.0712 & -0.0556 & 0.0119 & -0.1429 & 0.5571 \\
Nopember & -0.0582 & -0.0556 & 0.0147 & -0.0215 & 0.5089 \\
Desember & 0.0909 & -0.0556 & 0.0161 & 1.1535 & 0.1244 \\
\hline
\end{tabular}


Berdasarkan pengujian terhadap adanya autokorelasi spasial dengan menggunakan indeks Moran's (Tabel 2) menunjukkan bahwa pada bulan bulan Januari, Februari, Juli, Oktober dan Desember 2010 memiliki autokorelasi spasial positif. Sedangkan pada tahun 2011 sesuai dengan Tabel 3 terlihat tidak ada autokorelasi spasial positif maupun negatif pada bulan-bulan tersebut.Berdasarkan tingkat signifikan, menunjukkan bahwa bulanbulan tersebut mempunyai autokorelasi spasial dengan tingkat signifikan lebih dari $5 \%$. Hal ini mengindikasikan bahwa kedekatan lokasi kecamatan tidak hanya bersinggungan sisi atau tepi, namun lebih dari itu. Kedekatan ini dapat juga dipengaruhi oleh jarak yang menghubungkan dan tingkat mobilitas penduduk antar kecamatan. Oleh karena itu, kemungkinan matriks pembobot yang digunakan tidak hanya ketersinggungan saja, melainkan juga menggunakan pendekatan jarak antar kecamatan.

Analisis selanjutnya adalah dengan memperhatikan kejadian penyakit yang tertinggi yaitu pada bulan April 2010. Berdasarkan hasil Moran's Scatterplot pada bulan April 2010, diperoleh informasi bahwa sebagian besar angka kejadian penyakit DBD tiap kecamatan di Kabupaten Pekalongan pada bulan April 2010 menyebar di kuadran 1 (HH) dan kuadran 2 (LH). Pencaran titik-titik amatan pada Gambar 5 merupakan kecamatan yang menyebar berdasarkan pengaruhnya terhadap kecamatan yang bersebelahan. Titik pencar pada kuadran $1(\mathrm{HH})$ menunjukkan kecamatan yang angka DBD-nya tinggi berada di antara kecamatan-kecamatan yang angkan DBD-nya tinggi pula. Kuadran 2 (LH) menunjukkan kecamatan yang angka DBD-nya rendah berada di antara kecamatankecamatan yang angkan DBD-nya tinggi. Kuadran 3 (LL) menunjukkan kecamatan yang angka DBD-nya rendah berada di antara kecamatan-kecamatan yang angkan DBD-nya rendah pula. Kuadran 4 (HL) menunjukkan kecamatan yang angka DBD-nya tinggi berada di antara kecamatan-kecamatan yang angkan DBD-nya rendah. Kuadran HH dan LL mengindikasikan kesamaan karakteristik antar kecamatan (pola mengelompok) dan kuadran LH dan HL mengindikasikan keragaman karakteristik antar kecamatan.

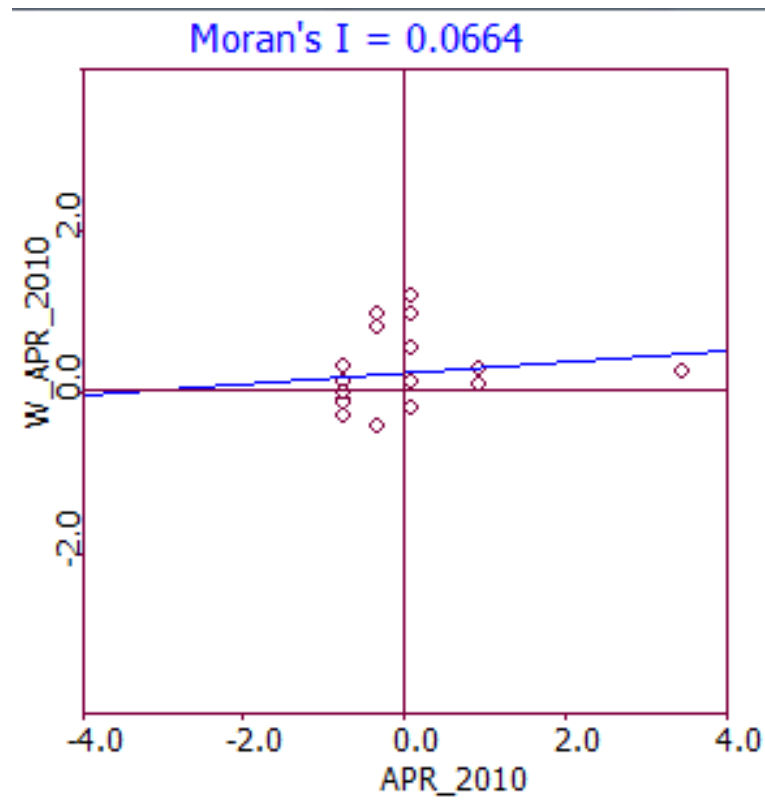

Gambar 5. Moran's Scatterplot penderita DBD pada bulan April 2010

Pengujian LISA memberikan hasil yang beragam. Kecamatan Kedungwuni, Wonopringgo, Karangdadap dan Tirto merupakan beberapa kecamatan yang memiliki hubungan spasial dengan kecamatan-kecamatan lain yang berdekatan. Hasil perhitungan nilai $I_{i}$ dan $p$-value untuk periode April 2010 selengkapnya disajikan pada Tabel 4. 
Tabel 4. Nilai Hitung dan p-value LISA pada Bulan April 2010

\begin{tabular}{lcclcc}
\hline Kecamatan & $\boldsymbol{I}_{\boldsymbol{i}}$ & p-value & Kecamatan & $\boldsymbol{I}_{\boldsymbol{i}}$ & p-value \\
\hline Buaran & 0.105 & 0.118 & Siwalan & -0.081 & 0.318 \\
Doro & 0.048 & 0.344 & Sragi & 0.012 & 0.384 \\
Kajen & -0.027 & 0.264 & Talun & 0.022 & 0.434 \\
Kandangserang & 0.022 & 0.358 & Tirto & -0.243 & $0.052^{\mathrm{b}}$ \\
Karangdadap & -0.295 & $0.014^{\mathrm{b}}$ & Wiradesa & 0.059 & 0.148 \\
Kedungwuni & 0.803 & $0.010^{\mathrm{a}}$ & Wonokerto & 0.227 & 0.318 \\
Kesesi & 0.012 & 0.316 & Wonopringgo & 0.129 & $0.012^{\mathrm{a}}$ \\
Lebakbarang & 0.104 & 0.478 & Karanganyar & -0.204 & 0.256 \\
Paninggaran & 0.140 & 0.252 & Bojong & 0.239 & 0.090 \\
Petungkriono & 0.124 & 0.390 & & & \\
\hline
\end{tabular}

${ }^{\mathrm{a}}$ Signifikan pada $\alpha=1 \%,{ }^{\mathrm{b}}$ Signifikan pada $\alpha=5 \%$

Hasil Moran's scatterplot dan LISA memberikan informasi bahwa kecamatan yang memiliki autokorelasi posistif adalah kecamatan Kedungwuni, Wonopringgo, dan Tirto. Sementara kecamatan yang memiliki autokorelasi negatif adalah Kecamatan Karangdadap. Hal ini dapat dijelaskan pula dengan gambar peta siginifikansi LISA pada Gambar 6. Sedangkan peta pengelompokkan kecamatan dapat dilihat pada Gambar 7.
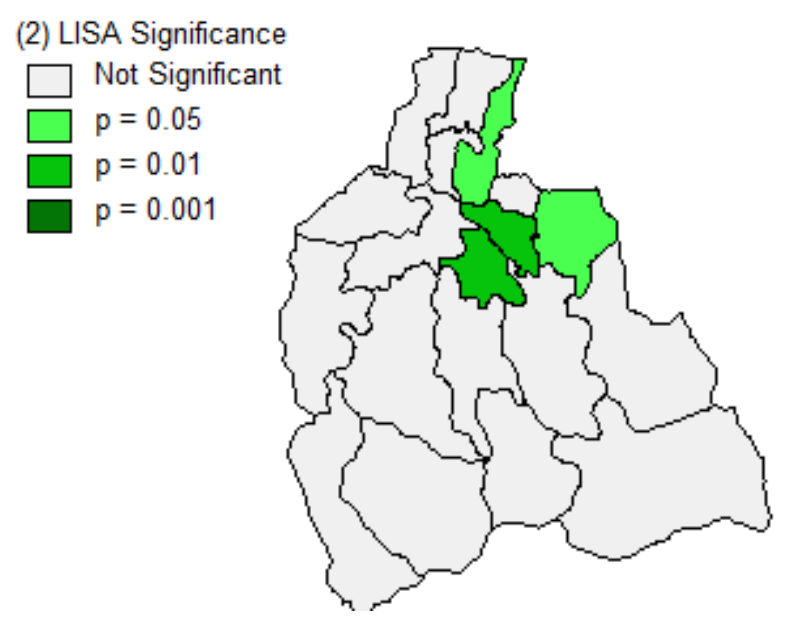

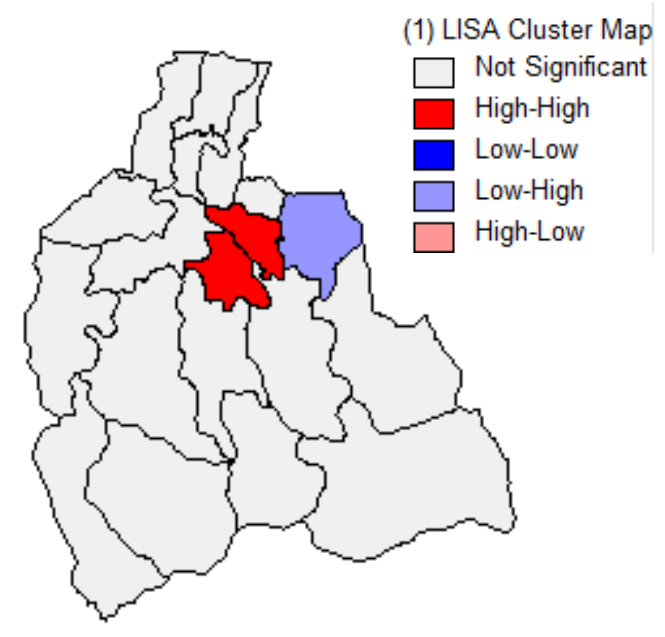

Gambar 6. Peta Signifikansi LISA dan Pengelompokkan Kecamatan April 2010

\section{Peta Endemisitas}

Tingkat kerawanan kecamatan terhadap ancaman penyakit DBD didasarkan pada kejadian DBD pada 3 tahun terakhir, yaitu tahun 2008, 2009 dan 2010. Oleh karena itu pada tahun 2011 di Kabupaten Pekalongan didapat hasil bahwa terdapat 14 kecamatan yang berstatus endemis, 3 kecamatan berstatus sporadis, dan 2 kecamatan berstatus aman/potensial. Pola penyebaran status kerawanan kecamatan dapat dilihat pada Gambar 7. Artinya dengan masih banyaknya kecamatan yang berstatus endemis, maka perlu penanganan yang lebih serius yang dapat menurunkan angka kejadian DBD. 


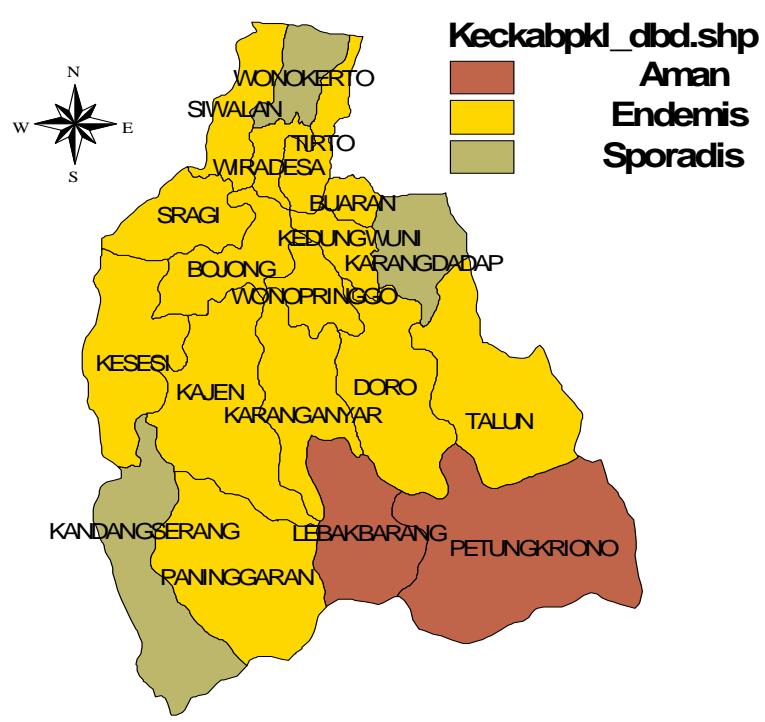

Gambar 7. Peta Sebaran Tingkat Kerawanan DBD Kabupaten Pekalongan Tahun 2011

\section{Kesimpulan}

Hasil analisis data menunjukkan bahwa kejadian DBD di Kabupaten Pekalongan sebagian besar terjadi pada musim hujan yaitu pada periode bulan Januari-Juni. Kejadian DBD cenderung lebih tinggi di Kecamatan Kedungwuni. Kejadian DBD tertinggi terjadi pada bulan April 2010. Selain itu, terdapat beberapa bulan yang mengindikasikan hubungan spasial pada kejadian DBD di Kabupaten Pekalongan, yaitu bulan Januari, Februari, Juli, Oktober dan Desember. Kecamatan yang memiliki autokorelasi posistif adalah kecamatan Kedungwuni, Wonopringgo, dan Tirto. Sementara kecamatan yang memiliki autokorelasi negatif adalah Kecamatan Karangdadap. Sebagian besar kecamatankecamatan di Kabupaten Pekalongan masih berstatus endemis terhadap kejadian DBD.

\section{DAFTAR PUSTAKA}

1. Curtis, J. A. and Lee, A. W., Spatial Pattern of Diabetes Related Health Problems for Vulneral Populations in Los Angeles, USA, 2010.

2. Dinkes Kab. Pekalongan, Profil Kesehatan Kabupaten Pekalongan 2011, 2011, URL: http://www.dinkes.pekalongankab.go.id, 7 Februari, 2012.

3. Ginanjar, G., Demam Berdarah, PT. Mizan Publika, Bandung, 2004.

4. Lee J. and Wong S.W.D., Statistical Analysis with Arcview GIS, John Willey \& Sons, Inc., United Stated of America, 2001.

5. Paradis, E., Moran's Autocorrelation, 2010, http://hosho.ees.hokudai.ac.jp/ kubo/Rdoc/library/ape/html/MoranI.html, 22-02-2012.

6. Rosli, M.H., Er, A.C., Asmahani, A., Naim, M.M.R., Harsuzilawati, M., Spatial Mapping of Dengue Incident: A Case Study in Hulu Langat District, Selangor, Malaysia, International Journal of Human and Social Sciences, 2010, Vol. 5, No. 6: $410-414$.

7. Sasmito, G.H. dan Widiatmoko, H., Informasi Meteorologi Untuk Peringatan Dini Bahaya Demam Berdarah Dengue (DBD) di Wilayah DKI Jakarta. Laporan Proyek Pengembangan Meteorologi dan Geofisika Tahun 2006, BMKG Jakarta, 2006.

8. Tottrup, C., Tersbol, P.B., Lindeboom, W. and Meyrowitsch, D., Putting Child Mortality on Map: Towards an Understanding of Inequity in Health, Tropical Medicine \& International Health, 2009, Vol. 14, No. $6:$ 653-662. 